\title{
ANALYSIS OF THE RECIPROCAL EFFECT OF IMPORTS OF NATURAL GAS AND OIL PRODUCTS ON ECONOMIC GROWTH IN KEPULAUAN RIAU DURING 2011 - 2018
}

\author{
$1^{\text {st }}$ Ashilya Puteri Sulaiman \\ Business Administration Study Program \\ Politeknik Negeri Batam \\ Batam, Indonesia \\ Email: ashilyapsulaiman@gmail.com
}

\author{
$2^{\text {nd }}$ Dwi Kartikasari, S.T., M.B.A. \\ Business Administration Study Program \\ Politeknik Negeri Batam \\ Batam, Indonesia \\ Email: dkartika414@gmail.com
}

\begin{abstract}
The purpose of this study is to determine the reciprocal effect of imports of natural gas and oil products on economic growth in Kepulauan Riau quarterly period during 2011 - 2018. This study uses secondary data types with quantitative approaches. The method used in this study is Generalized Structured Component Analysis with 32 quarterly samples during 2011 - 2018 obtained from the results of data collection at the Batam City Central Bureau of Statistics. The results show that the import of natural gas and oil products has a positive and significant effect on economic growth in the Kepulauan Riau and economic growth also has a positive and significant influence on the import of natural gas and oil products in the Kepulauan Riau.
\end{abstract}

Keywords: Economic Growth, Gross Domestic Product, Oil and Gas Imports.

\section{INTRODUCTION}

\section{A. Background}

Economic growth is a process where the economy of a country is said to be in a state of change continuously over a certain period of time towards a better time. Basically, economic growth is an increase in aggregate output which means the whole of goods and services produced by economic activity or Gross Domestic Product (GDP) which is the total value of the final output produced by an economy, whether carried out by citizens themselves or citizens foreigners residing in the country concerned.

Kepulauan Riau is one part of the implementation of national economic development in Indonesia. It is noted that the Kepulauan Riau economic growth is highest in 2012 at 7.63 percent while the lowest economic growth is in 2017 , which is 2 percent which is the lowest figure for the last 8 years. Every province in Indonesia including Kepulauan Riau must be able to face global economic problems where each province is asked to have high economic growth in circumstances where each region has the freedom to manage and use regional wealth for development activities in the area.

Kepulauan Riau has continuous import activities. The highest import value occurred in 2012 with a figure of US \$ 13,210 million. This happened because the resources in the Kepulauan Riau were unable to meet the very high demand so that imports were needed to cover it. One of the import sectors that has always experienced an increase is the oil and gas sector with an average increase of 1.29 percent annually.

Natural gas and petroleum are one of the commodities imported because both are one of the main energy sources that almost every country in the world uses in their daily lives. Indonesia was once a member of the Organization of the Petroleum Exporting Countries, which is a gathering place for countries that export oil in the world. However, since 2004, Indonesia is no longer able to produce petroleum and fulfill its needs so that now Indonesia is turning into a net importer of oil. As time went on, petroleum production declined from the previous year while domestic consumption from year to year always increased so that Indonesia had to leave OPEC in 2009.

The need for oil and natural gas is very high as happened in the Kepulauan Riau. The need for gas energy that occurs in various sectors such as industry, commercial, household, and power plants is the biggest demand. In the use of gas in the Kepulauan Riau Province there is an increase of an average of 4.2 percent annually in the industrial sector, 17.1 percent in the commercial sector and 28.5 percent in the household sector.

For oil energy use in Kepulauan Riau Province, the household and transportation sectors contribute the largest number each year. This is due to the shifting use of kerosene to fuel oil to LPG which tends to be cheaper and easier when compared to the use of kerosene. Meanwhile, in the transportation sector the use of premium type fuel oil averaged 288,715 kiloliters per year, pertalite types as much as 77,015 kilo liters per year, pertamax types as many as 26,645 kiloliters per year and diesel fuel as much as 86,140 kiloliters per year.

Petroleum oil types of gasoline / gasoline and diesel / diesel are the types of petroleum with the highest demand which is always imported in the Kepulauan Riau. Pertamina is a government agency that has authority in terms of imports and the sustainability of the availability of subsidized fuel.

\section{B. Formulation of The Research}

Based on the background described above, the formulation of the research problem is as follows: 
1) What is the influence of imports of natural gas and oil products on economic growth in the Kepulauan Riau?

2) What is the influence of economic growth on the import of natural gas and oil products in the Kepulauan Riau?

\section{Objectives of This Study}

Based on the formulation of the problem above, the objectives of this study are:

1) To find out how the influence of imports of natural gas and oil products on economic growth in the Kepulauan Riau

2) To find out how the influence of economic growth on imports of natural gas and oil products in the Kepulauan Riau

\section{Benefits}

The benefits obtained from this study include:

1) Practical benefits, as material for thought and information to interested parties in making policies and decisions, especially those related to economic growth and the implementation of imports in the Kepulauan Riau Province

2) Theoretical Benefits:

a) For Authors, it is expected that from this study the author can add experience, insight and learning as a practitioner in analyzing a problem then taking decisions and conclusions and applying the knowledge obtained during lectures.

b) For readers, as reference material or input for other researchers who have the same problem

\section{LITERATURE REVIEW}

\section{International Trade}

Trade is a transaction between the seller and the buyer that is based on their own will voluntarily. According to [10] international trade is a trading activity that occurs in a country with another country carried out by companies in the form of multinational corporations in the activities of transferring services, goods, capital, labor, technology and trademarks.

International trade is carried out with the aim that the fulfillment of resources that are not available in a country can be fulfilled due to international trade activities.

Exports and imports are activities that exist in international trade. Export is the activity of selling an item or service from one country to another. While imports are activities to buy goods or services from abroad to meet domestic needs. Export and import activities are mutually beneficial because they can increase the country's economy and meet domestic needs.

\section{Import}

According to [1] Imports are one indicator that can determine the success of a country because imports act as transportation of goods between countries officially. Imports involve two countries that have interests in which the country making the request is the buyer and the country that supplies it is the seller. According to [4] import also said that every item purchased must be reported to the Directorate General of Customs and Excise of the Ministry of Finance. So, from some of the meanings about imports above we can conclude that import is an activity of buying foreign goods domestically involving two or more countries officially and with the knowledge of the Directorate General of Customs and Excise of the Ministry of Finance.

Imports depend on the availability of goods or services produced in the country. If the needs and amount of production of a country are sufficient, import activities do not need to be done. But on the contrary if the number of production and needs are not sufficiently fulfilled, the import activities will continue until these needs are met. Indonesia itself is a country that relies heavily on import activities. There are so many resources or commodities that are actually owned domestically, but due to the huge demand and consumption while the production reserves are very thin, Indonesia must carry out import activities.

\section{Economic growth}

To be said to be prosperous, a region must show a significant increase in its economic growth when compared to other regions. Equitable income and needs of each individual in an area is one of the characteristics of high economic growth.

According to [7] the population, the amount of stock and capital, the area of land and natural wealth, and the level of technology are four factors that influence economic growth. Economic growth can also be interpreted as a process of increasing long-term production capacity from a country to supply of economic goods to the people.

Economic development and economic growth are two things that are inseparable. Economic growth can be seen based on the growth of Gross Domestic Income at constant prices to get real numbers. Whereas regional scale economic growth can be seen using the Per Capita Gross Domestic Product, therefore the level of welfare of a population can be known.

The hypothesis model is a temporary description of the results of the research that will be conducted. The hypothesis explains the relationship between the variables of Import of Natural Gas and Oil Products in the Kepulauan Riau and the Kepulauan Riau Economic Growth variable reciprocally. The hypothesis of this study are as follows:

H1: Imports of natural gas and Kepulauan Riau oil products have a positive and significant effect on economic growth

$\mathrm{H} 2$ : The economic growth of Kepulauan Riau has a positive and significant effect on the import of natural gas and oil products of the Kepulauan Riau

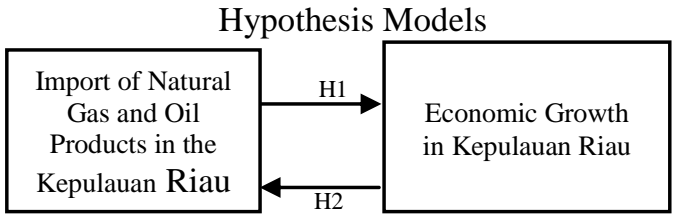

Fig 1 Hypothesis Model 


\section{RESEARCH METHODS}

This explanatory research uses quantitative data with secondary data sources with the aim of obtaining information about variables and differences between variables and indicators that produce real data that can explain the phenomena produced in each test.

\section{A. Validity and Reliability}

The validity test in this study was conducted by looking at the value of loading factors generated based on the analysis of the Gesca software, while the Cronbach's Alpha test was used to test reliability.

\section{B. Descriptive Analysis}

In this study, the descriptive statistics used were to present the minimum value, maximum value, average and standard deviation for each variable used in order to produce general data for the data to be sought and search for writers.

\section{Inferential Analysis}

Generalized Structure Component Analysis (GSCA) is a new method originally proposed by Hwang and Takane in 2004. According to [5] GSCA is part of a variant-based Structural Equation Model (SEM) which was developed with the aim of providing funds in Partial Least Square (PLS) that is in the overall Goodness of Fit Model. GSCA is a very powerful analysis method because it is not based on many assumptions. GSCA has a single criterion that can be used to minimize residuals in order to obtain model parameter estimates so that GSCA can provide optimal solutions and can provide connections to obtain the Overall Goodness of Fit Model.

\section{RESULT AND DISCUSSION}

\section{A. Validity and Reliability}

Based on the output from the GeSCA software, the results show that the loading factor value for the Economic Growth variable is 0.8322 and for Oil and Gas Imports is 0.7926 . This means that the indicators in this test have good validity and are said to be significant. while the output of the Cronbach's Alpha test obtained Alpha values of 0.7173 for the variable Economic growth and 0.7492 for the variable Import of Oil and Gas. This means that both variables have good reliability.

\section{B. Descriptive Analysis}

From 32 data analyzed by the author, the average result of economic growth variable is Rp. 29,564,235 billion with a maximum value of Rp. 44,992,330 billion and a minimum value of Rp. 10,602,105 billion and Rp. 14,169,445 billion for the standard deviation value.

\section{Generalized Structured Component Analysis \\ Evaluation of the Measurement Model}

In the validity test, the results obtained that the value of the loading factor for the Economic variable is 0.8322 and for the Import of Oil and Gas Results is 0.7926. This means that the indicators in this test have good validity and are recognized as significant. While for the reliability test, an
Alpha value of 0.7173 was obtained for the economic recovery variable and 0.7492 for the Import of Oil and Gas Results variable. This means that both variables have good reliability which has an alpha value greater than 0.70 .

\section{Evaluation of Structural Models}

Evaluation of structural models or inner models with the aim of finding out latent variables have a causal relationship. In this paper the author will obtain the results of estimation of path coefficients and significance levels that are useful in drawing conclusions from the research hypothesis. This study uses a confidence level of $95 \%(\alpha=$ $0.05)$ with a value of $T$.

Based on the results of the structural model path coefficient test, a significant result is obtained between Imports of Natural Gas and Oil Results on Economic Growth with an estimated value of $0.5101,0.0459$ for the standard error value and a critical ratio value of 11.113 . While the variable Economic Growth on Imports of Natural Gas and Oil Results, the estimated value is $0.511,0.0412$ for the standard error value and the critical ratio value is 12.403 .

TABLE I. COEFFICIENT OF STRUCTURAL MODEL PATH

\begin{tabular}{|c|c|c|c|c|}
\hline \multicolumn{4}{|c|}{ Path Coefficients } & \\
\hline & Estimate & $\mathrm{SE}$ & CR & \\
\hline $\begin{array}{c}\text { Imports of } \\
\text { Natural Gas } \\
\text { and Oil Yield } \\
\rightarrow \text { Economic } \\
\text { Growth }\end{array}$ & 0.5101 & 0.0459 & 11.113 & Significant \\
\hline $\begin{array}{c}\text { Economic } \\
\text { Growth } \rightarrow \\
\text { Imports of } \\
\text { Natural Gas } \\
\text { and Oil Yield }\end{array}$ & 0.511 & 0.0412 & 12.403 & Significant \\
\hline
\end{tabular}

Based on the results of the structural model path coefficient analysis, the hypothesis testing can be collected as follows:

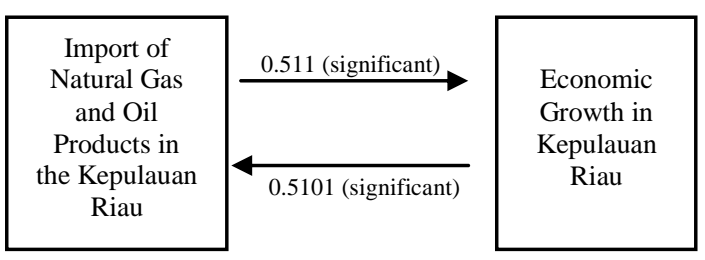

Fig 2. Value of The Structural Model Coefficient

Hypothesis 1: Imports of natural gas and oil products from Kepulauan Riau have a positive and significant effect on economic growth

The results of the analysis carried out using the General Structure Component Analysis method obtained the path coefficient of 0.5101 with a positive direction. For important natural gas and oil yield variables for economic growth, the Critical Ratio is obtained at 11.113 which means that this value is significant, the $\mathrm{CR}$ value is greater than 1.96 . so that it can be said that the import of natural gas and oil products has a significant influence on economic growth in the Kepulauan Riau and the first hypothesis (1) of this study is acceptable

Energy has an important role in the process of economic growth of a country in stabilizing economic growth. 
Sufficient energy supply is an expectation from every country. As one of the countries with high demand for fuel oil and refined petroleum products, Indonesia needs a very large energy source but unfortunately domestic energy production does not meet those needs.

Oil and gas imports by focusing on the import of oil and natural gas have the main function in providing the availability of energy needs through import activities which are expected to increase economic growth with smooth production and transportation processes.

Hypothesis 2: The economic growth of Kepulauan Riau has a positive and significant effect on the import of natural gas and oil products from the Kepulauan Riau

Based on the results of the analysis conducted by the author, the path coefficient value of 0.511 is obtained with a positive direction between the variables of economic growth and the import of natural gas and oil products in the Kepulauan Riau. The resulting Critical Ratio is 12,403, which means that the value is significant because the value of $\mathrm{CR}$ is more than 1.96. The results of this test show that economic growth has a positive and significant influence on imports of natural gas and oil products in the Kepulauan Riau, and thus the second hypothesis (2) of this study is acceptable.

The need for energy is one of the potential factors to support the sustainability of economic growth in a region or even a country. Seeing the condition of several regions in Indonesia including the Kepulauan Riau requires import activities which is the only way to cover the dependence on the consumption needs of oil and refined petroleum products.

Imports for natural gas in the Kepulauan Riau at the beginning of the study period did not show such a large number but the increase in imports of natural gas continued to increase over time. The increase occurred in the commercial, household and power sectors. This happens because the gas production capacity in the Kepulauan Riau is not sufficient to meet the needs that must be met.

\section{Evaluation of the Overall Model}

Evaluation on the overall model or overall model is done with the aim to see how well the model fits the data.

The testing of the FIT model shows a value of 0.5225 , which means that the difference of important natural gas and oil yield variables as well as economic growth variables in this structural model can explain phenomena that increase by 52 percent and 48 percent can be adjusted by other variables. The FIT value obtained from this test is greater than 0.05 , which means that the model is made appropriate and able to explain the phenomenon produced. For an Adjusted FIT value is $0.519,0.9863$ for GFI value and 0.0773 for Standardized Rood Mean Square (SRMR) value.

TABLE II. OVERALL MODEL PATH COEFFICIENT

\begin{tabular}{|c|c|}
\hline \multicolumn{2}{|c|}{ Overall Goodness of Fit Model } \\
\hline FIT & 0.5225 \\
\hline Adjusted FIT (AFIT) & 0.519 \\
\hline GFI & 0.9863 \\
\hline $\begin{array}{c}\text { Standardized Rood Mean Square } \\
\text { (SRMR) }\end{array}$ & 0.0773 \\
\hline
\end{tabular}

\section{CONCLUSIONS AND RECOMMENDATIONS}

\section{A. Conclusion}

Based on a series of evaluations that have been carried out in data analysis using the Generalized Structure Component Analysis method, the authors can conclude that:

1) In structural model path coefficient test, a significant result is obtained between Imports of Natural Gas and Oil Results on Economic Growth with an estimated value of $0.5101,0.0459$ for the standard error value and a critical ratio value of 11.113 . While the variable Economic Growth on Imports of Natural Gas and Oil Results, the estimated value is $0.511,0.0412$ for the standard error value and the critical ratio value is 12.403

2) In Evaluation of the Overall Model, FIT model shows a value of 0.5225 , for an Adjusted FIT value is 0.519, 0.9863 for GFI value and 0.0773 for Standardized Rood Mean Square (SRMR) value.

3) The results showed that the import natural gas and oil yield variables had a positive and significant effect on the variable economic growth in Kepulauan Riau quarterly period of 2011 - 2018. Oil and gas imports with indicators of natural gas and oil yield imports had a function as supply of domestic energy sector happened because of economic activities. The smoothness of economic activity driven by the availability of sufficient energy supplies will create an increase in economic growth.

4) The results showed that the economic growth variable had a positive and significant effect on the variable imports of natural gas and oil products in the Kepulauan Riau quarterly period of 2011 - 2018. The increase in energy consumption in the Kepulauan Riau was influenced by high rates of economic growth which had an impact on increasing energy needs. Energy production itself is not sufficient. Imports of natural gas and oil products are the solution to this condition so that an increase in the amount of imports of natural gas and oil products occurs and is in line with the increase in economic growth.

\section{B. Suggestion}

1) For the Government

a) The government as the policy maker is expected to be more careful in making policies regarding the import of natural gas and oil products and in making decisions on oil and gas subsidies.

b) The government is expected to be able to find market opportunities to diversify products in accordance with industrial capacity in the Kepulauan Riau.

c) The government can also increase the importance of raw materials by facilitating alternative raw materials that can be developed locally. 
2) For Researchers

a) Researchers are expected to be able to add or change variations of variables that help them to sharpen the theory in future research.

b) Researchers are expected to be able to increase the number of periods in subsequent studies so that the research results obtained are more accurate and clearly acceptable.

\section{ACKNOWLEDGEMENTS}

This thesis has been completed with the maximum thanks to cooperation, prayer, guidance, support, advice and assistance from various parties who have contributed maximally in the completion of this thesis. On this occasion, let the author say thank you profusely to:

1) Ms. Dwi Kartikasari, S.T., M.B.A as Chair of the Department of Business Management as well as a supervisor who has spent time in the midst of her busy activities to provide guidance, support, advice, guidance, advice, guidance in preparing this report.

2) All Lecturers, Academic Staff, Department Staff, Library Staff, and Civitas Polytechnic of Batam.

3) Parents, siblings, relatives and extended family that always motivate me to always be passionate about learning and graduation on time.

4) My best friend Siti Nidia Cahya, Annisa Rahma, Sisca Cahayani, Rudi Devika, Estri Oktriyanti, Faradila Putri, Iis Niar and Sis Onyak who always share stories and experiences so far

5) Colleague Class of Applied Business Administration both Regular and Employee classes.

\section{REFERENCES}

[1] Amalia, Lia. (2007). Ekonomi Internasional. Jakarta: Graha Ilmu dan UIEU.

[2] Badan Pusat Statistik Kota Batam. (2019). Perkembangan Ekpor dan Impor Provinsi Kepulauan Riau 2011 - 2018. Batam: Badan Pusat Statistik Kots Batam.

[3] Badan Pusat Statistik Kota Batam (2019). Potensi Daerah. Batam: Badan Pusat Statistik Kota Batam.

[4] Hamdani. (2014). Seluk Beluk Perdagangan Ekspor Impor. Jakarta: Yayasan Bina Usaha Niaga Indonesia.

[5] Hwang, H. \& Takane, Y. 2004. Generalized Structured Component Analysis. Psychometrika. 69(1):81-99.

[6] M.S, Amir. (2008). Handbook of Export-Import Bussiness. Jakarta: Victory Jaya Abadi.

[7] Kuncoro, Mudrajat. (2004). Otonomi dan Pembangunan Daerah. Jakarta: Erlanga.

[8] Sugiyono, P. D. (2008). Metode Penelitian Bisnis (Pendekatan Kuantitatif, Kualitatif dan R\&D). Bandung: Alfabeta.

[9] Undang - Undang Republik Indonesia Nomor 17 Tahun 2006 Tentang Perubahan Atas Undang - Undang Nomor 10 Tahun 1995 Tentang Kepabeanan.

[10] Wahyu, Harry. (2003). Ekonomi Internasional. Jakarta: Rineka Cipta 